\title{
NOTIONAL DEFINED CONTRIBUTION ACCOUNTS: AN APPLICATION TO MOROCCO
}

\author{
HiND EL-HOUJJAJI ${ }^{*}$, ABDELlAH ECHAOUI ${ }^{* *}$
}

\begin{abstract}
In order to deal with pension financial pressure, several countries have adopted notional defined contribution (NDC) system, which is a financial defined contribution system based on the Pay-As-You-Go (PAYG) principles. Investigating whether NDC could be an efficient solution for the pensions financial pressure in Morocco is a relevant question. In this paper we examine the potential financial results related to supposing a transition, in the CMR civilian regime, from PAYG system to NDC. We assume an immediate switching to NDC scheme in order to study the theoretical effects NDC can have on the actual system by using the model proposed by the French Council "Conseil d'Orientation des Retraites" (COR). Our results show that NDC could have financial benefices in the long-term, whereas it could not have in the short-term. Consequently, NDC seems to be not a relevant solution for the Moroccan pension system, so another solution should be investigated to improve the financial situation.
\end{abstract}

Keywords: notional defined contribution; social security reform; policy evaluation; CMR pension scheme; Morocco

JEL Classification: $G 23$; H55; $J 26$

\section{INTRODUCTION}

The Moroccan social security system is based on a PAYG mode where contributions of today workers finance benefits of retired people for the same period. This funding method, compared to others, is characterised by several defects mainly the system lack of legibility. The retirement system in Morocco is composed by two compulsory retirement regimes for the public sector workers

\footnotetext{
* Hind El-Houjjaji, Faculty of law, economic and social sciences-SOUISSI, Mohammed 5 University in Rabat, Morocco, elhoujjajihind@gmail.com

** Abdellah Echaoui, Faculty of law, economic and social sciences-SOUISSI, Mohammed 5 University in Rabat, Morocco, a.echaoui@um5s.net.ma
} 
namely the Moroccan Pension Fund, CMR (Caisse Marocaine des Retraites), and the Collective Scheme for Retirement Allowances, RCAR (Régime Collectif d'Allocation de Retraite). Likewise for the private sector workers, there is the National Social Security Fund, CNSS (Caisse Nationale de Sécurité Sociale). Nowadays, the Moroccan pension system has reached maturity, in other words, the amount of collected contributions no longer manage to finance that of pensions. In this situation, in a PAYG pension scheme, the financial situation is corrected using the reserves. But it should be noted that the annual consumption of the reserves will exhaust them. Among the pension plans mentioned above, the CMR presented the most urgent financial situation the deal with (see Cabinet Actuariat, 2010; Cour des Comptes, 2013).

The social security system over the world based on a PAYG funding method depends essentially on the adherents' contributions to finance retired and survived benefits. When these systems mature or in other words when the number of beneficiates exceeds one of the contributors, the regimes need to be reformed. There are two main types of reforms specifically parametric ones and systemic ones. The first type is based on changing the system parameters such as the contribution rate and the retirement age while the second type depends on changing the system funding operation. Given the importance of the transfer charges to a new funding operation, the deficit retirement systems are unable to adopt a defined contribution model such as that adopted by Chile since early 1980s. This was the reason for what the Sued invented the NDC.

On one hand, an NDC scheme operates like a funded plan to the point that contributions of NDC plan members are managed via individual accounts. On the other hand, it keeps the management foundations of a PAYG principle as the current contributions of adherents finance benefits for retirees of the same period. In general, the NDC funding system is a financial defined contribution system based on the PAYG principles as the NDC system keeps the PAYG financing method while it adopts the funded, defined contribution systems award and indexation formulas. As explained by Börsch-Supan (2005), adopting NDC funding method don't change the basic PAYG mechanism in which contributors of a specific period finance retired ones of the same period and they do not create savings unless they reduce benefits which imply saving rates reductions.

As cited above, the NDC funding method was created by the Sued but before adopting it, the country has had a testing ground where she established the new regime. The country helped in 1996 and 1999 respectively Latvia and Poland to introduce the new system. Thereafter, Sweden introduced it in 1999 with a 
transitional period of 20 years and Italy for new entrants since 1st January 1996. Lindeman et al (2006) explained the speed of transition and its causes which was different from one country to another. Sweden had the fastest transition, namely all cohorts of people are covered by the new system. While Italy had the longest one where cohorts born before 1960 stayed in the old system which means that pensions according to old regime in Italy will be paid until around 2030 or even later. In Sweden, the speed of the transition from the PAYG pension scheme to the NDC was possible due to the good database of individual records dating from 1960 that permits calculating notional accounts for cohorts born in 1938 and older. In addition, the only change in the new Sweden pension system was the benefit formula.

Holzmann (2017) mentioned that "the basic conceptual structure of any NDC scheme is the consistent link between the individual level of its design and the macroeconomic level. At individual level, an NDC scheme promises income smoothing and intra-generational equity as it creates a strong contributionbenefit link. At macro level, an NDC scheme promises intergenerational equity and financial sustainability while remaining unfunded". Furthermore, NDC plan makes it possible to avoid the difficult transition from a distribution system to capitalization in spite of the fact that NDC mechanism adopts various capitalization qualities. In fact, NDC is a financing method that grants both collective solidarity and individual equity. More precisely, the solidarity is maintained between generations through the use of distribution whereas the individual equity is maintained by the fact that each adherent finds the equivalent of its own contributory effort.

So in general, the high costs of switching to a fully funding method and the success and positive results of implanting the NDC financing method in several European countries are encouraging reasons to establish a notional account pension plan. In addition, we should not forget the limited results of parametric reforms on improving the financial situation of pension plans which their results remain limited in time.

To our best knowledge, this paper is the first work to study the eventual theoretical effects of switching to a new pension plan based on NDC funding mode. For that, we will use the NDC equations presented by the COR (Conseil D'orientation des Retraites) (Des Retraites; 2010) on the population existing in 2014 on the CMR civilian pension regime. Our approach is based on studying and analysing the theoretical financial effects of switching to an NDC plan. This work can be taken into account as a basis for the development of appropriate reforms to the CMR civilian pension regime. It gives several and useful policy implications to 
the researchers and policymakers and this work can be developed in future by studying different reforms combinations.

Following this introduction, the remainder of the article is presented in four sections. The next section gives a brief overview of the existing literature which studied the possibility of implementing NDC pension plan in several countries. This is followed by the empirical methodology used in the study. The main findings are presented and discussed. The final section summarizes the study conclusions.

\section{LITERATURE REVIEW}

To preserve PAYG pension funds from insolvency, two types of reforms structure can be distinguished: parametric reforms and transition to an actuarially fair system (Volkov; 2010). In Morocco, the government promulgated in 2015 a parametric reform to improve the pension fund financial sustainability. Nevertheless, it is shown very often in the literature that a parametric reform is just a temporal solution and the need is for structural reforms. The costs of switching to new funded pension fund make it impossible. This was the reason why Sweden invented a new pension fund structure which combined both funded and unfunded structures. Holzmann (2017) discussed the emergence of the idea about NDC, the experiences of countries that adopted this financial technique. Furthermore, he presented how NDC works and its main technical boundaries. Gronchi and Nistico (2008) compared the NDC financing mode properties with those of defined-benefit.

NDC experience has had great success due to its financial stability in the countries where it was implemented. According to Volkov (2010), this is explained by the fact that "a quasiactuarial system is characterized by greater financial stability than a nonactuarial one, since it has some features of a funded system (the amount of money in notional accounts depends on the citizens' contributions, although the return on investments is zero, or even negative in real terms). Switching to a quasiactuarial system strengthens the connection between contributions and benefits and provides Pareto improvement thanks to smaller distortions of the labor market and a more balanced system."

Börsch-Supan (2005) presented NDC taxonomy and clarified its pros and cons. In addition, he showed that properly designed NDC public pension systems contain powerful economic and political mechanisms that may facilitate pension reform. Knell (2018) explained that for implementing a financially stable NDC pension system in the presence of life expectancy, policymakers must arrange the notional interest rate, the adjustment rate and the annuity conversion factor in an appropriate way. 
The World Bank has shown interest in the NDC reforms, so it has presented three books on this issue explaining the financing mode, the experience of countries that adopted the NDC model, and countries where it's question to adopt an NDC financing mode as a reform (Holzmann and Palmer, 2006; Holzmann et al, 2012a, b).

The experience success in different countries where it was implemented pushed the researchers to study the possibility of adopting the same financing mode. In Europe, for example, Palmer (2002) argues that adopting an NDC financing mode would made the exit from the workforce more flexible and would remove obstacles to labor mobility in Europe. Moreover, Honekamp (2007) compared pension fund stability dealing with an ageing population in two countries, namely Sweden and Germany.

The rate of population aging is increasing in the developing world and the trend is particularly dramatic in East Asia. It is the principle reason for what some papers studied the possibility of implementing NDC retirement pension, such in Japan (e.g. Lu et al, 2008; Takayama, 2006) or in China (e.g. Oksanen, 2012). Some papers compared the effect of implementing NDC on different countries, such as Williamson et al (2012) who studied the potential value of the notional defined contribution model in two countries from east Asia (China and Singapore) and one from south Asia (South Korea).

NDC financing mode has sparked interest not only in Europe or Asia but also in the US. Min and Seo (2012) proposed an NDC reform due to the population and financial sustainability. Boskin et al (1988) made a NDC reform proposal to the US Social Security for Old Age, Disability and Survivors.

Despite his notoriety, the lack of redistribution mechanisms in NDC systems is still discussed. Ventura-Marco and Vidal-Melia (2016) developed a theoretical basis for integrating retirement and permanent disability using a generic nonfinancial defined contribution framework. Furthermore, Halvorsen and Pedersen (2019), study the distributional effects of the reformed Norwegian pension system, which is based on NDC financing mode, with a particular focus on gender equality.

\section{THE NDC STRUCTURE}

As indicated by his name, an NDC plan is a defined contributions regime which works like a PAYG one due to the fact that contributions collected from actual contributors serve to finance pensions to the retirees of the same period. The difference between NDC and PAYG lies not only in the level of contributions but 
also in benefits. These are a function of several parameters in a PAYG plan while it is a function of contributions collected during the working life of the contributor. These contributions represent the individual savings of contributors collected into individual accounts called notional accounts as is the case in a plan managed by capitalization or by points. But these accounts are not real savings assets, indeed, they are intermediaries of calculations. This is what is called virtual accounts in the case of NDC plans because the balance is fictional (or "notional") since no real capital is accumulated.

Each year, this account is revalued based on an indexation to inflation (like in Suede) or wage trends (like in both Poland and Latvia), or GDP (like in Italy) (Des Retraites; 2010). As in capitalisation, when the adherent enters retirement, his virtual account is converted into annual pensions through actuarial coefficients (named conversion coefficients) that take into account life expectancy. In fact, they are calculated according to the retirement age and not to the contribution period which is the case in PAYG plans. More precisely, the conversion coefficient is calculated for each generation. Thereby, for a given generation, the payment of this pension over the entire expected retirement period exhausts at the end of life the virtual capital still indexed. In fact, the virtual capital is divided by the number of years remaining to live.

The NDC funding model represents four several advantages compared to PAYG financing model, namely, a better recognition of modest wage careers and a best consideration of the inequality of life expectancies. Furthermore, this financing mode separates income replacement from redistributive considerations and finally it is a good way for politicians. These advantages are presented above.

In the actual pension system the calculation of the retirement pension is based on a reference salary which is actually the average of the last eight wages in the CMR pension regime. This method of calculation advantages staffs with a strong salary increase during their careers, especially at the end of the period (Bozio and Piketty; 2008), contrariwise, it disadvantages employees with low salaries. With the introduction of NDC plan, the pension becomes the result of individual savings during the working life period so even the lowest salaries of the career are integrated in the pension calculation. In fact, each employee has a fictitious personal account which enables him to a retirement pension. The latter is proportional to the contributions collected during his working life, knowing that any contribution paid gives additional rights, and not even an extension of the old salary. According to the COR simulations, a notional system would conduct, all things being equal, to a redistribution of the highest pensions to the lowest pensions. 
Moreover, benefits in NDC plan are indexed to longevity due to the annuitization mechanism and to employment through a correctly computed notional rate of interest. This leads an NDC system to be automatically adjusting to changes in both life expectancy and macroeconomic environment (Börsch-Supan; 2005).

Furthermore, an NDC scheme is designed without redistribution mechanisms which is an important aspect for transparency but may introduce redistributive measures. However, redistributive interventions have to be clearly introduced into the scheme (Holzmann; 2017). In fact, the introduction of NDC mechanism should be accompanied by the establishment of additional devices to recreate noncontributory benefits.

And finally, the NDC system makes people think in accounts because any contribution paid gives additional rights, and it's a good way for politicians (Cichon; 1999) as it makes the transition to partial funding psychologically easier (Börsch-Supan; 2005).

\section{MATERIALS AND METHODS}

In PAYG managed systems, the retirement pension is determined in terms of the wage (the last one or an average of working years). While in NDC managed system, the retirement pension is based on an actuarial equivalence between contributions collected during working life and benefits will be versed in retirement period. This calculation is done individual by individual by the fact that each adherent has an individual account functioning as saving account where the contributions versed during his working life are collected. This is a virtual account which is an intermediate calculation tool used to compute the retirement pension. To study the theoretical effects of implementing NDC financing mode in Morocco, we will use the model clarified by the COR (Des Retraites; 2010).

Each adherent to the system accumulates during his working life a virtual capital $\mathrm{C}$ which is the discounted sum of the collected contributions and is expressed as follows:

$$
C=\sum_{x-x_{r}}^{x_{r}-1} \tau^{c n} \cdot S_{i}(x) \cdot\left(1+r^{o b s}\right)^{x_{r}-x},
$$

Where, $x_{1}$ is the recruitment age, $x_{r}$ is the retirement age, $\tau^{c n}$ is the contribution rate, $S_{i}$ is the salary of the individual $i$ at age $\mathrm{x}$ and $r^{o b s}$ is the virtual capital revaluation rate. 
More specifically, the initial retirement pension is actuarially calculated as a lifelong annuity. The initial pension under notional accounts is calculated by making the sum of contributions paid during working life equal to the sum of pensions that the retiree receives until death. In fact, the actualized amount of pension flows must be equal to the accumulated virtual capital.

$$
\sum_{x=x_{r}}^{\omega} \frac{P_{i}\left(x_{r}\right) \cdot(1+g)^{x-x_{r}}}{\left(1+r^{p r o j}\right)^{x-x_{r}}} \times p\left(x_{r} ; x\right)=C,
$$

Where $r^{p r o j}$ is the expected rate of return of the virtual capital, $g$ is the rate of pension revaluation, $p\left(x_{r} ; x\right)$ is the probability of survival between age $x_{r}$ and age $x$, and $\omega$ represents the age of death.

We put:

$$
\frac{1}{1+a}=\frac{1+g}{1+r^{\text {proj }}}
$$

The equation (2) can be written as follows:

$$
P_{i}\left(x_{r}\right) \cdot \sum_{x-x_{r}}^{\omega} \frac{p\left(x_{r}, x\right)}{(1+a)^{x-x_{r}}}=C,
$$

The conversion coefficient therefore verifies the following relationship:

$$
\frac{1}{G}=\sum_{x=x_{r}}^{\omega} \frac{(1+g)^{x-x_{r}}}{\left(1+r^{\text {proj }}\right)^{x-x_{r}}} \times p\left(x_{r} ; x\right)=\sum_{x-x_{r}}^{\omega} \frac{p\left(x_{r}, x\right)}{(1+a)^{x-x_{r}}},(5)
$$

where $G$ is the conversion coefficient and $a$ is defined as the actualization rate on which depends the conversion coefficient.

Hence, the retirement pension $\mathrm{P}$ at the liquidation date is equal to the virtual capital $C$ accumulated on the retirement liquidation date, multiplied by the conversion coefficient $G$. It is calculated as follows:

$$
P_{i}\left(x_{r}\right)=G . C,
$$

NDC financing model takes into account the risk of longevity in calculating the pension through the conversion coefficient. The latter depends particularly on the survival probability at the retirement age which tends to evolve generation after generation. 
Particularly, if the revaluation rate $g$ is equal to $r^{p r o j}$, then $a$ is equal to zero and the conversion coefficient is equal to the inverse of the life expectancy . Namely, the latter at age $x_{r}$ is the sum of the probabilities of survival at each age.

\section{The projection assumptions}

We suppose in this paper an immediate transition from PAYG to NDC funding mode so as to study and observe immediately the consequences of setting up an NDC plan (Blanchet; 2009). This scenario is not realistic, but it allows us to observe the immediate consequences of adopting NDC financed plan. Our projections are based on the population existing in 2014 on the CMR civilian regime. We base our simulations on the hypotheses presented in Table 1, where are presented the projection variables and their hypothetical values.

Table 1. Projection assumptions

\begin{tabular}{lc}
\hline \multicolumn{1}{c}{ Variable } & Hypothetical value \\
\hline Contribution rate & $20 \%$ \\
\hline Rate of virtual capital revaluation* & $4.6 \%$ \\
\hline Salary evolution rate & $4.5 \%$ \\
\hline Pension revaluation rate & $1 \%$ \\
\hline Discount rate & $4 \%$ \\
\hline $\begin{array}{l}\text { we choose it to be equal to the average growth rate for the last five years (same parameter chosen } \\
\text { in Sweden. As a result, we will take a fixed annual virtual interest rate). }\end{array}$
\end{tabular}




\section{RESULTS AND DISCUSSION}

In this paper, we projected the financial situation evolution of the CMR's civilian pension regime, based on the assumptions mentioned above (See Table 1) during the period 2014-2064. The simulations show the theoretical effects on switching to NDC financing mode.

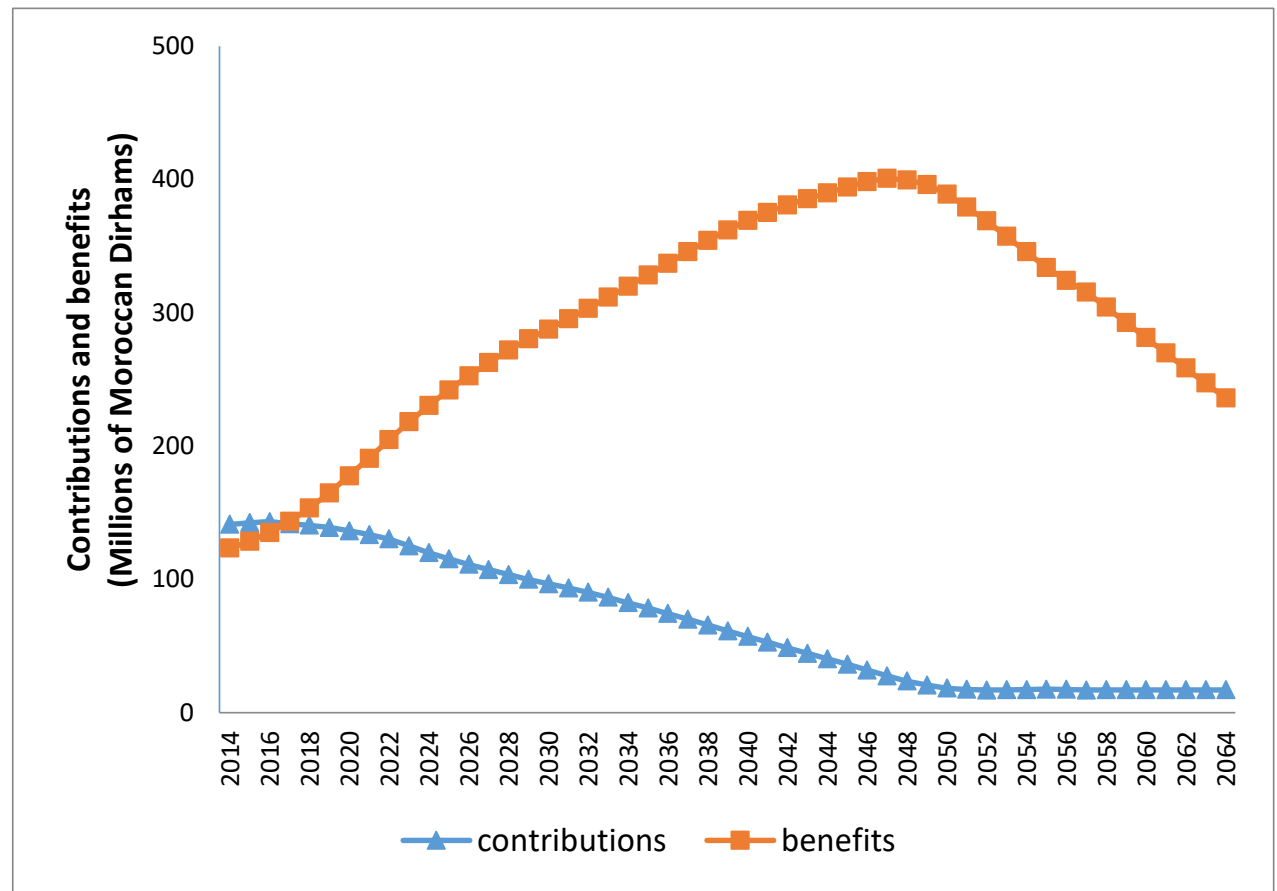

Figure 1: Projection of the CMR's civilian regime contributions and benefits under NDC funding mode (millions of Moroccan Dirhams)

As shown in Figure 1, adopting NDC financing mode will impact the amount of contributions collected by the pension scheme and in the same time the total benefits paid to retirees. During all the projection period, the population is a relatively stable. This stability is must be due to the recruitment politic in the public sector, where the number of new employees replaces that of retired, disables and deceased ones. In additions, the decrease in the number of workers contributing to the system is must be due also to the lack of employment in the formal sector. Accordingly, in the end of projection, the contributions value will be fix start of 2050 . 
The amount of benefits stills so important compared to that of contributions. It must be due to the important number of retirees existing in the scheme compared to that of contributors. It could be also explained by the fact that NDC financing mode takes in consideration the total wages earned during working life.

As presented in Figure 1, the sum of contributions collected by the plan exceeds that of benefits paid by it at the beginning of the period because the plan is surplus. However, it would decrease and be nil in 2017, which reflect the theoretical functioning of the notional account regime with a relatively stable population.

Benefices of adopting the NDC funding mode will be perceived start of 2050, when the amount of benefits will start to decrease. This is explained by the one advantage of NDC model comparing to PAYG financing mode is that it will, at least in the long run, help keep pension benefits in balance with the available contributions (Williamson and Shen, 2004)

The results are owing to the contributions and benefits indexation (Lindeman et al; 2006). The results can be improved by adopting another indexation mode. Furthermore, the NDC financing mode encourages working longer as benefit entitlements rise with a longer working period. $\mathrm{Lu}$ et al (2008) explained that defined benefit pension systems tends to cap or reduce increases in benefits after a certain stipulated contribution period, but it is frequently claimed that an NDC scheme, contrariwise, encourages people to work longer.

The reserve fund in the PAYG systems is used to manage unexpected fluctuations in the covered payroll. If the reserve fund is well invested, it will guarantee a rate of return that exceeds the PAYG return, this alleviating the decline in the PAYG return. Lindeman et al (2006) explained that there are two reasons to establish larger buffer funds "One reason is to smooth out known variations in demographics - for example, a baby boom, followed by a baby bust, followed by replacement fertility rates. The other reason is to manage unknown long-term demographic trends, such as a move from one birth rate pattern to another (for example, two plus to two minus children per woman). Such long-term trends can be mitigated by buffer funds". In 
this paper, we study the theoretical impact of adopting an NDC financing mode on the amount of the reserves (Figure 2).

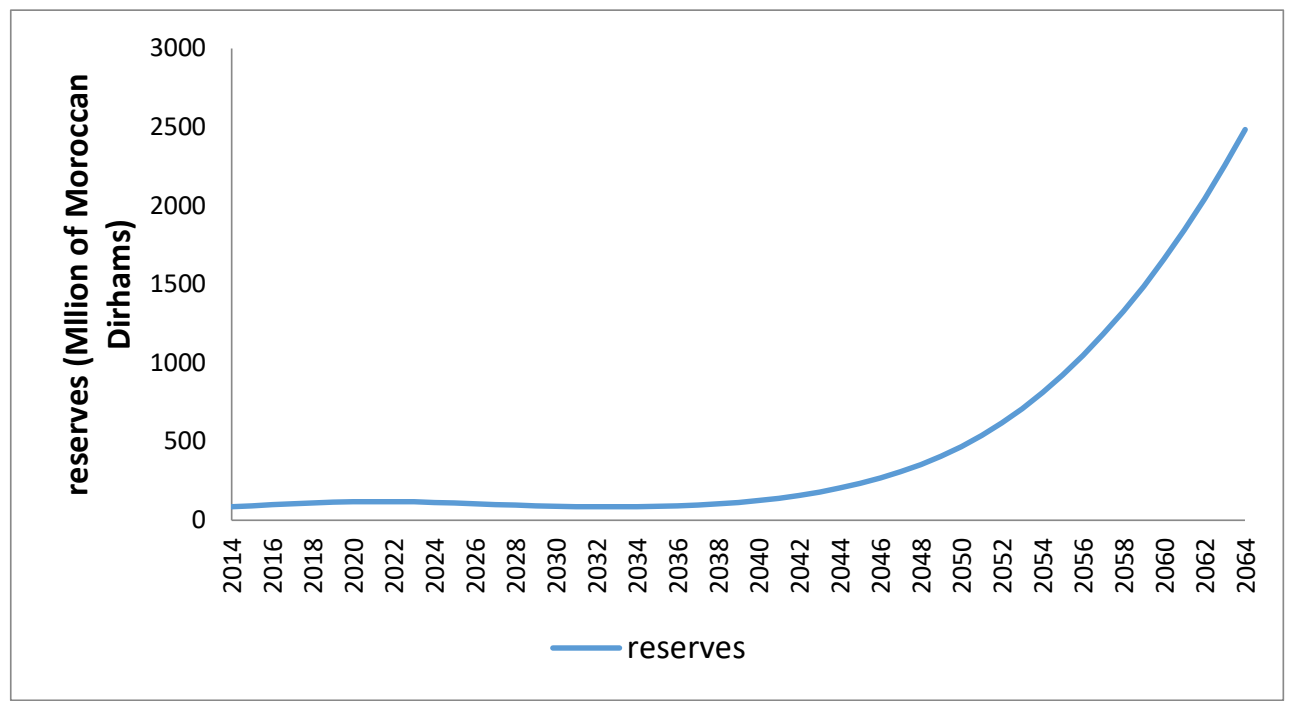

Figure 2. The CMR reserve projection under NDC funding mode (millions of Moroccan Dirhams)

Even so the amount of benefits is such important compared to that of contributions during the projection period that will not impact the reserves. The latter will still positive and is relatively stable during the period 2014-2040 but will know an exponential increase by the end of the projection period. This must be due to the fact that the pension scheme adopting NDC funding mode paid only one type of benefits namely retirement ones which are the result of individual saving. In addition, an NDC pension scheme delivers lower pensions than those delivered by PAYG pension scheme.

An NDC financing mode is transparent towards the system members. In fact, they can consult the amount of their contributions at any moment during their working life and their benefits are the direct result of the sum of their contributions. This transparency provides an incentive to stay in the labor force longer (Gray \& Weig, 1999) which can have impact and improve results in Figure 1.

We should note that NDC does not offer a solution for countries facing an important disequilibrium in the short term (Valdés-Prieto, 2000). This is an important consideration because most of the countries that adopted NDC financing mode, did so at a time of short-term fiscal crisis, when their pre-existing annuity regimes were very unbalanced. The introduction of the NDC scheme was generally accompanied with a couple of contribution increases and benefit reductions. In 
some cases the inflation was a cause that reduced the amount of benefits promised under the prior PAYG system. This combination of reforms is part of the solution, especially in the transition economies despite that it has sometimes been a partial flaw on previous promises. In general, over the long-term which is a period of several decades, the NDC model help to keep a pension system in balance, but in the short-term and particularly the first few years this funding mode will by itself be of little if any help.

It would be hard to get popular support for a radical change in the system as Volkov (2010) explained that there is no transparency or clear correspondence between contributions and benefits. Contrariwise, it may be that people are more willing to accept it especially when it is clear that the current benefit structure is not sustainable or because they prefer the new scheme structure and the control it gives them over their eventual pension benefit.

Despite its important advantages, the NDC financing mode can be refused by people due to its limits. In this plan, an adherent must pay an additional contribution to get access to the non-contributory benefits. Contrariwise to the PAYG plan which is characterised by solidarity, the NDC one works like a funded plan for this type of benefits. In fact, the NDC plan is characterised by the reduction of solidarity because each plan member receives a retirement pension based on the sum of contributions made during his working life. In addition, Börsch-Supan (2005) mentioned that NDC systems are well positioned to manage the challenge of longevity. More precisely, they react to slow changes-in fertility through the internal rate of return, but not to sudden changes in fertility.

\section{CONCLUSION}

In Morocco, the financial problem of pension schemes is not about demographic ageing but it is specially a demographic problem within the pension scheme as the total number of retirees exceeds that of contributors. The contrast number of contributors and retirees may be due directly to two causes. The first is the recruitment politic in the public sector, as the number of new employees replaces that of retired, disabled and deceased ones and the second is the lack of formal sector jobs. To improve the financial situation, policymakers in Morocco should deal with these causes.

In 2015, the government adopted a parametric reform intended to deal with the critical financial situation of the CMR civilian regime. Accordingly, this parametric reform pushes adherents to pay higher contributions for lower benefits. Moreover, the poorly written rules in the elaboration of the retirement pension 
scheme that was created in the colonization period, are not actualized since then. During the existence of the CMR civilian regime, a sole reform has been adopted to increase the contribution rate from $14 \%$ to $20 \%$. However, the pension scheme doesn't take into consideration changes at the level of population (life expectancy, etc.) and economic policies (employment, etc.). For this reason, this study investigates the possibility of establishing a new financing mode, namely the NDC mode, that several developed and developing countries has already adopted to solve pension financial pressure. In this context, we examined the theoretical effects that the actual system can undergo in case of an immediate switching to NDC scheme. For that, we use the model proposed by the "Conseil d'Orientation des Retraites" (COR).

The NDC system has several advantages as it allows a better recognition of modest wage careers, a best consideration of the inequality of life expectancies, and separating income replacement from redistributive considerations. Nevertheless, the NDC financing mode has a number of considerable disadvantages. We quote mainly, the important ones. First, the level of pensions will be lower under the NDC financing mode than PAYG. Second, the annuity system has so far ensured a "standard of living between retirees and assets", which would not necessarily be the case for another system. Third, the NDC plan is characterised by the reduction of solidarity because each plan member receives a retirement pension based on the sum of contributions made during his working life. Fourth, it is a system deprived of all his contributory advantages and adherents must pay an additional contribution to get access to the non-contributory benefit.

Our results show that NDC is beneficial in the long term, whereas in the short term it is not. Nevertheless, the Moroccan pension scheme needs solution in the short term. Consequently, it would be preferred to preserve the existing pension system than transitioning to NDC system.

However, the current system is still unsatisfactory and a more relevant solution should be investigated to improve the financial situation. As a suggestion, some recruitment policies could be set to increase the number of employees, and make formal the informal sector. Furthermore, some positive NDC characteristics can be added to the implemented PAYG regime to then obtain a more performant system. 


\section{REFERENCES}

1. Blanchet, D. (2009). Transition vers un système en comptes notionnels: quelques scénarios exploratoires portant sur le cœur du système. Document préparatoire au septième rapport du Conseil d'Orientation des Retraites.

2. Börsch-Supan, A. (2005). From traditional DB to notional DC systems: The pension reform process in Sweden, Italy, and Germany. Journal of the European Economic Association, 3(2-3), 458-465.

3. Boskin, M., Kotlikoff, L. J., \& Shoven, J. (1988). A proposal for fundamental social security reform in the 21st century. Lexington-Lexington Books, Massachusetts.

4. Bozio, A., \& Piketty, T. (2008). Pour un nouveau système de retraite. Des comptes individuels de cotisations financés par répartition, Collection du Cepremap.

5. Cabinet Actuariat (2010), commission technique sur la réforme des retraites, rapport final de l'étude: Synthèse des travaux.

6. Cichon, M. (1999). Notional defined-contribution schemes: Old wine in new bottles? International Social Security Review, 52(4), 87-105.

7. Cour des Comptes (2013), Rapport sur le système de retraite au Maroc, diagnostic et propositions de réformes.

8. Des Retraites, C. D. O. (2010). Retraites: annuités, points ou comptes notionnels. Options et modalités techniques, Septième rapport du COR.

9. Gray, C., \& Weig, D. (1999). Pension System Issues and Their Relation to Economic Growth'CAER II Discussion Paper No. 41. Harvard Institute for International Development, available

at: http://www.hiid.harvard.edu/projects/caer/papers/paper41/paper41.html.

10. Gronchi, S., \& Nisticò, S. (2008). Theoretical foundations of pay-as-you-go defined-contribution pension schemes. Metroeconomica, 59(2), 131-159.

11. Halvorsen, E., \& Pedersen, A. W. (2019). Closing the gender gap in pensions: A microsimulation analysis of the Norwegian NDC pension system. Journal of European Social Policy, 29(1), 130-143.

12. Holzmann, R., \& Palmer, E. (Eds.). (2006). Pension reform: issues and prospects for non-financial defined contribution (NDC) schemes. The World Bank.

13. Holzmann, R., Palmer, E., \& Robalino, D. (Eds.). (2012a). Nonfinancial Defined Contribution Pension Schemes in a Changing Pension World: Volume 1: Progress, Lessons, and Implementation. The World Bank.

14. Holzmann, R., Palmer, E., \& Robalino, D. (2012b). Nonfinancial Defined Contribution Pension Schemes in a Changing Pension World: Volume 2 Gender, Politics, and Financial Stability. The World Bank.

15. Holzmann, R. (2017). The ABCs of nonfinancial defined contribution (NDC) schemes. International Social Security Review, 70(3), 53-77.

16. Honekamp, I. (2007). PAYG in an ageing society: The case of Sweden versus Germany. Pensions: an international journal, 12(3), 138-153.

17. Knell, M. (2018). Increasing life expectancy and NDC pension systems. Journal of Pension Economics \& Finance, 17(2), 170-199.

18. Lindeman, D., Robalino, D. A., \& Rutkowski, M. (2006). NDC Pension schemes in middle-and low-income countries. Pension reform: Issues and prospects for nonfinancial defined contribution (NDC) schemes, 293-324. 
19. Lu, B., Mitchell, O. S., \& Piggott, J. (2008). Notional defined contribution pensions with public reserve funds in ageing economies: An application to Japan. International Social Security Review, 61(4), 1-23.

20. Min, H., \& Seo, J. (2012). Applicability of the notional defined contribution (NDC) model in United States social security: Comparing the NDC model and the defined benefit model. International Review of Public Administration, 17(1), 33-53.

21. Oksanen, H. (2012). China: Pension reform for an aging economy. Progress, Lessons, and Implementation, 1, 213-58.

22. Palmer, E. (2002). Is Swedish pension reform the right medicine for aging Europe?, Journal of aging \& social policy, 14(1), 35-52.

23. Takayama, N. (2006). Reforming social security in Japan: Is NDC the answer?, Pension reform: Issues and prospects for non-financial defined contribution (NDC) schemes, 639-647.

24. Valdes-Prieto, S. (2000). The financial stability of notional account pensions. Scandinavian Journal of Economics, 102(3), 395-417.

25. Ventura-Marco, M., \& Vidal-Meliá, C. (2016). Integrating retirement and permanent disability in NDC pension schemes. Applied Economics, 48(12), 1081-1102.

26. Volkov Ia. (2010), Modeling Pension Reforms and Estimating Implicit Pension Debt, Problems of Economic Transition, vol. 52, no. 11, pp. 4-23.

27. Williamson, J. B., \& Shen, C. (2004). Do notional defined contribution accounts make sense as part of the old-age security mix for China?, Journal of aging \& social policy, 16(4), 39-57.

28. Williamson, J. B., Price, M., \& Shen, C. (2012). Pension policy in China, Singapore, and South Korea: An assessment of the potential value of the notional defined contribution model. Journal of Aging Studies, 26(1), 79-89. 